\title{
Frequency of the CCR5 432 allele in Brazilians: a study in colorectal cancer and in HTLV-I infection
}

\author{
Rinaldo W. Pereiral, Edina R. Pires ${ }^{2}$, Ana P.M. Duarte ${ }^{3}$, Ricardo P. de Moura ${ }^{3}$, Elisangela Monteiro ${ }^{3}$, \\ Humberto Torloni ${ }^{2}$, Anna B. Proietti ${ }^{4}$, Andrew J.G. Simpson ${ }^{3}$ and Sérgio D.J. Pena ${ }^{1,5}$
}

\begin{abstract}
The identification of a 32-bp deletion in the cc-chemokine receptor-5 gene (CCR5 432 allele) that renders homozygous individuals highly resistant to HIV infection has prompted worldwide investigations of the frequency of the CCR5 32 allele in regional populations. It is important to ascertain if $C C R 5 \Delta 32$ is a factor to be considered in the overall epidemiology of HIV in individual populations. With this in mind we determined the CCR5 $\triangle 32$ allele frequency in a large sample (907 individuals) of the southeastern Brazilian urban population, stratified as follows: 322 healthy unrelated individuals, 354 unselected colorectal cancer patients, and 229 blood donors. The three groups displayed essentially identical allelic frequencies of CCR5 432 and pairwise comparisons did not show significant differences. Thus, our results can be pooled to provide a reliable estimate of the $C C R 5 \Delta 32$ allele frequency in the southeastern Brazil of $0.053 \pm$ 0.005 . The blood donors comprised 50 HTLV-I serologically negative individuals, 115 non-symptomatic individuals HTLV-I positive by ELISA but with indeterminate Western blot results, 49 healthy blood donors HTLV-I positive both at ELISA and Western blot and 15 patients with clinical spinal cord disease (HAM). A suggestive trend was observed, with the CCR5 32 frequencies decreasing progressively in these four categories. However, when we applied Fischer's exact test no significant differences emerged. We believe that further studies in larger cohorts should be performed to ascertain whether the CCR5 $\Delta 32$ allele influences the chance of becoming infected or developing clinical symptoms of HTLV-I infection.
\end{abstract}

\section{INTRODUCTION}

The cc-chemokine receptor-5 gene protein (CCR5) is a seven-transmembrane-domain $\mathrm{G}$ protein coupled receptor that has as its natural ligands RANTES (regulated on activation normal T-cell expressed and secreted), MIP-alpha (macrophage inflammatory protein) and MIP-beta, which are members of the CC subfamily of chemokines (Samson et al., 1996a). The CCR5 protein, in concert with $\mathrm{CD} 4$, is also the receptor that mediates the internalization of HIV in macrophages and monocytes (Dragic et al., 1996). Studies of individuals who have been multiply exposed to $\mathrm{HIV}$ and yet remain uninfected led to the identification of the CCR5 432 allele, that exhibits a 32-bp deletion in the CCR5 gene (Liu et al., 1996). Because of a frameshift at amino acid 185 the deleted allele codes for a truncated protein that is consequently not integrated into the cell membrane (Liu et al., 1996). The homozygous state for the CCR5 $\Delta 32$ allele has been shown to be associated with a high degree of protection against HIV infection in vivo (Dean et al., 1996; Huang et al., 1996; Samson et al., 1996b). This protection is not absolute as demonstrated by identification of one HIV-1-infected CCR5 32 homozygote (Biti et al., 1997; O'Brien et al., 1997). Although there is no evidence for a strong protective effect in heterozygotes (Dean et al., 1996; Huang et al., 1996; Michael et al., 1997), a modest reduction in HIV incidence has been reported (Samson et al., 1996b). Also, the observation that cohorts of long-term survivors are enriched for CCR5 $\Delta 32$ heterozygotes suggests the existence of some protection against the AIDS progression (Dean et al., 1996; Huang et al., 1996; Michael et al., 1997).

The CCR5 332 allele is common in North America and Europe, with heterozygote frequencies varying from 10 to 20\% in Caucasians (Dean et al., 1996; Huang et al., 1996; Liu et al., 1996; Samson et al., 1996b; Martinson et al., 1997). In Eurasia $C C R 5 \Delta 32$ frequencies show a north-south gradient with the highest allele frequencies in Finnish and Mordvinian populations (16\%) and the lowest in Sardinia (4\%) (Libert et al., 1998). The CCR5 32 allele is not found in aboriginal populations outside Eurasia (Martinson et al., 1997; Leboute et al., 1999; Lu et al., 1999). The presence of $C C R 5 \Delta 32$ allele elsewhere throughout the world probably represents recent European gene flow into local populations (Martinson et al., 1997). The origin of the CCR5 432 has been speculatively dated to approximately 700 years

${ }^{1}$ Laboratório de Genética Bioquímica, Universidade Federal de Minas Gerais, Belo Horizonte, MG, Brasil. Send correspondence to S.D.J.P. Departamento de Bioquímica e Imunologia, ICB,

UFMG, Caixa Postal 486, 30161-970 Belo Horizonte, MG, Brasil. Fax: +55-31-227-3792. E-mail: spena@dcc.ufmg.br

${ }^{2}$ Hospital do Câncer A.C. Camargo, São Paulo, SP, Brasil.

${ }^{3}$ Ludwig Institute for Cancer Research, São Paulo, SP, Brasil.

${ }^{4}$ Fundação Hemominas, Alameda Ezequiel Dias, Belo Horizonte, MG, Brasil.

${ }^{5}$ GENE - Núcleo de Genética Médica, Belo Horizonte, MG, Brasil. 
ago, with its frequency increasing rapidly as consequence of a strong selective pressure, possibly an ancient plague (Stephens et al., 1998). A possible candidate is the bubonic plague that claimed the lives of 25-33\% of Europeans in the 14th century (Stephens et al., 1998).

HTLV-I is a retrovirus from the oncoretroviridae family with variable prevalence rate in human populations. The vast majority of HTLV-I-infected individuals have no associated symptoms. However, 1 in every 1000-2000 individuals with positive serology per year develop adult T-cell leukemia/lymphoma (ATLL) (Poiesz et al., 1980; Tajima, 1990) and other patients may present with myelopathy (HAM) (Gessain et al., 1985). The prevalence of the latter has been estimated to be $2.4 \%$ in the United States (Murphy et al., 1997) but only about $0.07 \%$ among the Japanese (Osame et al., 1990). Several genetic aspects, viral or human, have been tested as possible determinants of clinical course of the HTLV-I infection. Among the viral markers, tax mutations (Renjifo et al., 1995) and the proportion of synonymous and non-synonymous mutations on the tax have been tested (Niewiesk and Bangham, 1996). Regarding host genetic markers, the HLA polymorphisms are the main class tested until now, mostly with weak associations (LaGrenade et al., 1996; Sonoda et al., 1996; Jeffery et al., 1999). Recently we have tested polymorphisms of endogenous retroviral sequences (Pereira, R.W., Proietti, A.B. and Pena, S.D.J., unpublished results) but did not see any association with one of the clinical outcome of HTLV-I infection.

Inter-population differences in CCR5 32 frequency may influence the pattern of HIV transmission and will need to be incorporated into future predictions of HIV levels (Martinson et al., 1997). We thus considered it important to establish the frequency of CCR5 32 allele in the Brazilian population to support future studies in groups at risk of HIV infection. Moreover, we evaluated two special groups: patients with colorectal cancer and patients with HTLV-I infection.

\section{MATERIAL AND METHODS}

We analyzed 322 unrelated Brazilian individuals randomly chosen among unrelated participants in paternity testing studies. Most of the patients were self-classified as "white" and originated from the southeast region of Brazil. We also studied 354 unselected colorectal cancer patients from the Hospital do Câncer A.C. Camargo in São Paulo. Finally, 229 individuals participating in a cohort study at Fundação Hemominas were distributed as follows: $50 \mathrm{HTLV}$ I seronegative individuals, 115 non-symptomatic individuals HTLV-I positive at the ELISA test but with indeterminate Western blot results, 49 healthy blood donors HTLV-I positive both at ELISA and Western blot and 15 HTLV-I patients with clinical spinal cord disease (HAM). Consent was obtained from all participants and all analyses were performed anonymously.
The deletion in CCR5 was assayed by means of the polymerase chain reaction (PCR) with previously described primers (Samson et al., 1996b). PCR was carried out with 20 pmol of each primer, $0.1 \mathrm{mM}$ dNTPs, $1.5 \mathrm{mM} \mathrm{MgCl} 2$ $75 \mathrm{mM} \mathrm{KCl}, 10 \mathrm{mM}$ Tris- $\mathrm{HCl}, \mathrm{pH} \mathrm{8.3}$, and 1 unit of Taq polymerase in a final volume of $20 \mu \mathrm{l}$. Cycle conditions were: initial denaturation of $94^{\circ} \mathrm{C}$ for $3 \mathrm{~min}$ and 30 cycles of $94^{\circ} \mathrm{C}$ for $1 \mathrm{~min}, 62^{\circ} \mathrm{C}$ for $2 \mathrm{~min}, 72^{\circ} \mathrm{C}$ for $1 \mathrm{~min}$, followed by a final extension step of $72^{\circ} \mathrm{C}$ for $5 \mathrm{~min}$. A sample of the reaction product $(5 \mu \mathrm{l})$ was run on $5 \%$ polyacrylamide gels and visualized by silver staining (Santos et al., 1993). Typing was unambiguous, the wild type allele and the CCR $5 \Delta 32$ allele generating fragments of $735 \mathrm{bp}$ and $703 \mathrm{bp}$, respectively.

The allele frequencies were calculated by gene counting. The Hardy-Weinberg equilibrium of the groups and the significance level of the genotypic and allelic frequency differences between groups were calculated using Fisher's exact test.

\section{RESULTS}

Our three groups (healthy individuals, colorectal cancer patients and blood donors) displayed essentially identical allelic frequencies of CCR5 $\Delta 32$ (Table I) and pairwise comparisons did not show significant differences. In all the groups the genotype frequencies did not deviate significantly from the Hardy-Weinberg equilibrium. Thus, our results can be pooled to provide a reliable estimate of the $C C R 5 \Delta 32$ allele frequency in southeastern Brazil of $0.053 \pm 0.005$, which agrees with previous estimates (Martinson et al., 1997).

Within the blood donor patients, we compared the allelic and genotypic frequency of CCR5 32 in four groups: HTLV-I negative healthy blood donors, HTLV-IELISA positive and Western blot negative healthy individuals, ELISA and Western blot positive non-symptomatic individuals, and ELISA and Western blot positive symptomatic patients with HAM (Table II). A suggestive trend was observed, with the CCR5 $\Delta 32$ frequencies decreasing progressively in these four categories. However, as expected from the small number of symptomatic patients and the broad confidence limits of the CCR5 $\triangle 32$ allele frequencies, no significant differences were obtained when we applied the Fischer's exact test.

\section{DISCUSSION}

The Brazilian population is predominantly of European ancestry with significant contributions from African and Amerindian gene pools (Pena et al., 2000). Since the CCR5 32 allele has not been identified in Africans (Martinson et al., 1997) or Amerindians (Martinson et al., 1997; Leboute et al., 1999), the presence of the CCR5 32 allele in Brazilians can be attributed to European immigration. The 0.053 frequency of $C C R 5 \Delta 32$ allele that we ob- 
Table I - Determination of the CCR5 332 allele frequency in the urban population of southeastern Brazil.

\begin{tabular}{|lccccc|}
\hline Population & $\mathrm{N}$ & \multicolumn{5}{c}{ Genotype } & $\begin{array}{c}\text { CCR } 32 \text { frequency } \\
\text { (95\% binomial } \\
\text { confidence limits) }\end{array}$ \\
\cline { 3 - 6 } & & CCR5/CCR5 & CCR5/CCR5 32 & CCR5 32/CCR5 332 & 0.054 \\
Healthy individuals & 324 & 289 & 35 & 0 & $(0.038-0.074)$ \\
Cancer patients & 354 & 318 & 34 & 2 & 0.054 \\
Blood donors & 229 & 205 & 24 & 0 & $(0.036-0.070)$ \\
Total & 907 & 812 & 93 & 2 & 0.052 \\
& & & & & $0.034-0.077)$ \\
& & & & & 0.053 \\
\end{tabular}

Table II - Determination of the CCR5 32 allele frequency in blood donors with different status in reference to HTLV-I infection.

\begin{tabular}{|c|c|c|c|c|c|}
\hline \multirow[t]{2}{*}{ Blood donors } & \multirow[t]{2}{*}{$\mathrm{N}$} & \multicolumn{3}{|c|}{ Genotype } & \multirow{2}{*}{$\begin{array}{c}\text { CCR } \Delta 32 \text { frequency } \\
\text { (95\% binomial } \\
\text { confidence limits) }\end{array}$} \\
\hline & & $C C R 5 / C C R 5$ & CCR5/CCR5 532 & CCR5 $\triangle 32 / C C R 5 \Delta 32$ & \\
\hline ELISA + WB negative & 50 & 43 & 7 & 0 & $\begin{array}{c}0.070 \\
(0.029-0.139)\end{array}$ \\
\hline $\begin{array}{l}\text { ELISA positive, WB } \\
\text { indeterminate }\end{array}$ & 115 & 102 & 13 & 0 & $\begin{array}{c}0.057 \\
(0.030-0.095)\end{array}$ \\
\hline $\begin{array}{l}\text { ELISA + WB positive, } \\
\text { non-symptomatic }\end{array}$ & 49 & 45 & 4 & 0 & $\begin{array}{c}0.041 \\
(0.011-0.101)\end{array}$ \\
\hline $\begin{array}{l}\text { ELISA + WB positive, } \\
\text { symptomatic with HAM }\end{array}$ & 15 & 15 & 0 & 0 & $\begin{array}{c}0.000 \\
(0.000-0.116)\end{array}$ \\
\hline Total & 229 & 205 & 24 & 0 & $\begin{array}{c}0.052 \\
(0.034-0.077)\end{array}$ \\
\hline
\end{tabular}

WB, Western blot.

served in our sample is lower than the average frequency in Europe (0.10), reflecting the African and Amerindian contributions. A previous estimate of the CCR5 32 allele frequency among Brazilian individuals was 0.035 , but only 100 individuals were studied (Passos and Picanco, 1998). At any rate, the $C C R 5 \Delta 32$ allele frequency will fluctuate according to the proportion of European versus African or Amerindian ancestry in the sample.

The CCR5 32 allele frequency in patients with colorectal cancer was exactly the same as in healthy individuals. When we compared the frequencies in relation to HTLV-I infection a suggestive trend was observed with the frequency decreasing progressively among the four categories of blood donors (Table II). However, when we applied Fischer's exact test no significant differences emerged. We believe that further studies in larger cohorts should be performed to ascertain whether the $C C R 5 \Delta 32$ allele influences the chance of becoming infected or developing clinical symptoms of HTLV-I infection.

\section{ACKNOWLEDGMENTS}

Research supported by grants from FAPEMIG and CNPq. R.W.P. is the recipient of a PhD studentship from CAPES. Publication supported by FAPESP.

\section{RESUMO}

A observação de que indivíduos homozigotos para uma deleção de 32 pares de base no gene que codifica para o receptor 5 de cc-quimiocinas apresentam um menor risco de contrair a infecção por HIV-1 levou à investigação da freqüência deste polimorfismo em várias populações mundiais. É importante investigar se o $C C R 5 \Delta 32$ é um fator a ser considerado na epidemiologia do HIV em populações individuais. Com estes pressupostos em mente nós estabelecemos a freqüência do CCR5 $\Delta 32$ em uma grande amostra (907 indivíduos não-relacionados) da população urbana do sudeste brasileiro, estratificada da seguinte maneira: 322 indivíduos sadios, 354 pacientes com câncer colorretal e 229 doadores de sangue. Os três grupos apresentaram essencialmente a mesma frequiência alélica de CCR5 332 e a comparação par-apar não revelou diferenças significativas. Assim, os nossos resultados podem ser agrupados para fornecer uma estimativa confiável de $0,053 \pm 0,005$ da frequiência alélica de CCR5 432 . Os doadores de sangue compreendiam 50 indivíduos soronegativos para HTLVI, 115 indivíduos assintomáticos por ELISA mas com resultados indeterminados em Western blot, 49 indivíduos soropositivos para HTLV-I mas assintomáticos e 15 indivíduos soropositivos para HTLV-I sintomáticos com mielopatia. Foi observado um sugestivo gradiente decrescente da freqüência alélica de CCR5 $\Delta 32$ nestas categorias. Entretanto, quando aplicamos o teste exato de Fisher, não emergiram diferenças significativas. Para uma melhor avaliação da influência do alelo $C C R 5 \Delta 32$ na probabilidade de infectar-se 
com HTLV-I ou de desenvolver doença clínica serão necessários estudos com um maior número de doadores de sangue.

\section{REFERENCES}

Biti, R., Ffrench, R., Young, J., Bennetts, B., Stewart, G. and Liang, T. (1997). HIV-1 infection in an individual homozygotes for the CCR5 deletion allele. Nat. Med. 3: 252-253.

Dean, M., Carrington, M., Winkler, C., Huttley, G.A., Smith, M.W., Allikmets, R., Goedert, J.J., Buchbinder, S.P., Vittinghoff, E., Gomperts, E., Donfield, S., Vlahov, D., Kaslow, R., Saah, A., Rinaldo, C., Detels, R. and O'Brien, S.J. (1996). Genetic restriction of HIV-1 infection and progression to AIDS by a deletion allele of the CKR5 structural gene. Hemophilia Growth and Development Study, Multicenter AIDS Cohort Study, Multicenter Hemophilia Cohort Study, San Francisco City Cohort, ALIVE Study. Science 273: 1856-1862.

Dragic, T., Litwin, V., Allaway, G.P., Martin, S.R., Huang, Y., Nagashima, K.A., Cayanan, C., Maddon, P.J., Koup, R.A., Moore, J.P. and Paxton, W.A. (1996). HIV-1 entry into CD4+ cells is mediated by the chemokine receptor CC-CKR-5. Nature 381: 667-673.

Gessain, A., Barin, F., Vernant, J.C., Gout, O., Maurs, L., Calender, A. and de The, G. (1985). Antibodies to human T-lymphotropic virus type-I in patients with tropical spastic paraparesis. Lancet 2: 407-410.

Huang, Y., Paxton, W.A., Wolinsky, S.M., Neumann, A.U., Zhang, L., He, T., Kang, S., Ceradini, D., Jin, Z., Yazdanbakhsh, K., Kunstman, K., Erickson, D., Dragon, E., Landau, N.R., Phair, J., Ho, D.D. and Koup, R.A. (1996). The role of a mutant CCR5 allele in HIV-1 transmission and disease progression. Nat. Med. 2: 1240-1243.

Jeffery, K.J., Usuku, K., Hall, S.E., Matsumoto, W., Taylor, G.P., Procter, J., Bunce, M., Ogg, G.S., Welsh, K.I., Weber, J.N., Lloyd, A.L., Nowak, M.A., Nagai, M., Kodama, D., Izumo, S., Osame, M. and Bangham, C.R. (1999). HLA alleles determine human T-lymphotropic virus-I (HTLV-I) proviral load and the risk of HTLV-I-associated myelopathy. Proc. Natl. Acad. Sci. USA 96: 3848-3853.

LaGrenade, L., Sonoda, S., Miller, W., Pate, E., Rodgers-Johnson, P., Hanchard, B., Cranston, B., Fujiyoshi, T., Yashiki, S., Blank, M., Gibbs, C.J. and Manns, A. (1996). HLA DRB1*DQB1* haplotype in HTLV-Iassociated familial infective dermatitis may predict development of HTLVI-associated myelopathy/tropical spastic paraparesis. Am. J. Med. Genet. 61:37-41.

Leboute, A.P., de Carvalho, M.W. and Simoes, A.L. (1999). Absence of the deltaccr5 mutation in indigenous populations of the Brazilian Amazon. Hum. Genet. 105: 442-443.

Libert, F., Cochaux, P., Beckman, G., Samson, M., Aksenova, M., Cao, A., Czeizel, A., Claustres, M., de la Rua, C., Ferrari, M., Ferrec, C., Glover, G., Grinde, B., Guran, S., Kucinskas, V., Lavinha, J., Mercier, B., Ogur, G., Peltonen, L., Rosatelli, C., Schwartz, M., Spitsyn, V., Timar, L., Beckman, L., Parmentier, M. and Vassart, G. (1998). The $\Delta$ ccr5 mutation conferring protection against HIV-1 in Caucasian populations has a single and recent origin in Northeastern Europe. Hum. Mol. Genet. 7: 399-406.

Liu, R., Paxton, W.A., Choe, S., Ceradini, D., Martin, S.R., Horuk, R., MacDonald, M.E., Stuhlmann, H., Koup, R.A. and Landau, N.R. (1996). Homozygotes defect in HIV-1 coreceptor accounts for resistance of some multiply-exposed individuals to HIV-1 infection. Cell 86: 367-377.

Lu, Y., Nerurkar, V.R., Dashwood, W.M., Woodward, C.L., Ablan, S., Shikuma, C.M., Grandinetti, A., Chang, H., Nguyen, H.T., Wu, Z., Yamamura, Y., Boto, W.O., Merriwether, A., Kurata, T., Detels, R. and Yanagihara, R. (1999). Genotype and allele frequency of a 32-base pair deletion mutation in the CCR5 gene in various ethnic groups: absence of mutation among Asians and Pacific Islanders. Int. J. Infect. Dis. 3: $186-191$.

Martinson, J.J., Chapman, N.H., Rees, D.C., Liu, Y.T. and Clegg, J.B. (1997). Global distribution of the CCR5 gene 32-basepair deletion. Nat. Genet.
16: 100-103.

Michael, N.L., Louie, L.G., Rohrbaugh, A.L., Schultz, K.A., Dayhoff, D.E., Wang, C.E. and Sheppard, H.W. (1997). The role of CCR5 and CCR2 polymorphisms in HIV-1 transmission and disease progression. Nat. Med. 3: 1160-1162.

Murphy, E.L., Fridey, J., Smith, J.W., Engstrom, J., Sacher, R.A., Miller, K., Gibble, J., Stevens, J., Thomson, R., Hansma, D., Kaplan, J., Khabbaz, R. and Nemo, G. (1997). HTLV-associated myelopathy in a cohort of HTLV-I and HTLV-II-infected blood donors. The REDS investigators. Neurology 48: 315-320.

Niewiesk, S. and Bangham, C.R. (1996). Evolution in a chronic RNA virus infection: selection on HTLV-I tax protein differs between healthy carriers and patients with tropical spastic paraparesis. J. Mol. Evol. 42: $452-458$.

O'Brien, T.R., Winkler, C., Dean, M., Nelson, J.A., Carrington, M., Michael, N.L. and White 2nd, G.C. (1997). HIV-1 infection in a man homozygotes for CCR5 delta 32. Lancet 349: 1219.

Osame, M., Janssen, R., Kubota, H., Nishitani, H., Igata, A., Nagataki, S., Mori, M., Goto, I., Shimabukuro, H., Khabbaz, R. and Kaplan, J. (1990). Nationwide survey of HTLV-I-associated myelopathy in Japan: association with blood transfusion. Ann. Neurol. 28: 50-56.

Passos Jr., G.A. and Picanco, V.P. (1998). Frequency of the $\Delta$ ccr5 deletion allele in the urban Brazilian population. Immunol. Lett. 61: 205-207.

Pena, S.D.J., Carvalho-Silva, D.R., Alves-Silva, J., Prado, V.F. and Santos, F.R. (2000). Retrato molecular do Brasil. Ciênc. Hoje 27: 16-25.

Poiesz, B.J., Ruscetti, F.W., Gazdar, A.F., Bunn, P.A., Minna, J.D. and Gallo, R.C. (1980). Detection and isolation of type C retrovirus particles from fresh and cultured lymphocytes of a patient with cutaneous T-cell lymphoma. Proc. Natl. Acad. Sci. USA 77: 7415-7419.

Renjifo, B., Borrero, I. and Essex, M. (1995). Tax mutation associated with tropical spastic paraparesis/human T-cell leukemia virus type I-associated myelopathy [published erratum appears in J. Virol. 1995 Jun;69:3964]. J. Virol. 69: 2611-2616.

Samson, M., Labbe, O., Mollereau, C., Vassart, G. and Parmentier, M. (1996a). Molecular cloning and functional expression of a new human CCchemokine receptor gene. Biochemistry 35: 3362-3367.

Samson, M., Libert, F., Doranz, B.J., Rucker, J., Liesnard, C., Farber, C.M., Saragosti, S., Lapoumeroulie, C., Cognaux, J., Forceille, C., Muyldermans, G., Verhofstede, C., Burtonboy, G., Georges, M., Imai, T., Rana, S., Yi, Y., Smyth, R.J., Collman, R.G., Doms, R.W., Vassart, G. and Parmentier, M. (1996b). Resistance to HIV-1 infection in Caucasian individuals bearing mutant alleles of the CCR-5 chemokine receptor gene. Nature 382: 722-725.

Santos, F.R., Pena, S.D.J. and Epplen, J. (1993). Genetic and population study of a Y-linked tetranucleotide repeat DNA polymorphism with a simple non-isotopic technique. Hum. Genet. 90: 655-656.

Sonoda, S., Fujiyoshi, T. and Yashiki, S. (1996). Immunogenetics of HTLV-I/ II and associated diseases. J. Acquired Immune Defic. Syndr. Hum. Retrovirol. 13: S119-S123.

Stephens, J.C., Reich, D.E., Goldstein, D.B., Shin, H.D., Smith, M.W., Carrington, M., Winkler, C., Huttley, G.A., Allikmets, R., Schriml, L., Gerrard, B., Malasky, M., Ramos, M.D., Morlot, S., Tzetis, M., Oddoux, C., di Giovine, F.S., Nasioulas, G., Chandler, D., Aseev, M., Hanson, M., Kalaydjieva, L., Glavac, D., Gasparini, P., Kanavakis, E., Claustres, M., Kambouris, M., Ostrer, H., Duff, G., Baranov, V., Sibul, H., Metspalu, A., Goldman, D., Martin, N., Duffy, D., Schmidtke, J., Estivill, X., O'Brien, S.J. and Dean, M. (1998). Dating the origin of the CCR5- 332 AIDS-resistance allele by the coalescence of haplotypes. Am. J. Hum. Genet. 62: 1507-1515.

Tajima, K. (1990). The 4th nation-wide study of adult T-cell leukemia/lymphoma (ATL) in Japan: estimates of risk of ATL and its geographical and clinical features. The T- and B-Cell Malignancy Study Group. Int. J. Cancer 45: 237-243.

(Received August 31, 2000) 